\title{
Identification, tissue expression, and glucocorticoid responsiveness of alternative first exons of the human glucocorticoid receptor
}

\author{
Elisabeth Presul ${ }^{1}$, Stefan Schmidt ${ }^{1,2}$, Reinhard Kofler ${ }^{1,2}$ and Arno Helmberg ${ }^{1}$ \\ ${ }^{1}$ Biocenter, Division of Molecular Pathophysiology, Innsbruck Medical University, Fritz Pregl Str 3, A 6020 Innsbruck, Austria \\ ${ }^{2}$ Tyrolean Cancer Research Institute, Innrain 66, 6020 Innsbruck, Austria \\ (Requests for offprints should be addressed to A Helmberg; Email: arno.helmberg@i-med.ac.at)
}

\begin{abstract}
Transcripts for the human glucocorticoid receptor (NR3C1) are known to contain alternative first exons $1 A 1,1 A 2$, and $1 \mathrm{~A} 3$ from the distal promoter or $1 \mathrm{D}, 1 \mathrm{E}, 1 \mathrm{~B}, 1 \mathrm{~F}, 1 \mathrm{C}$, or $1 \mathrm{H}$ from the proximal promoter. Here, we report two additional alternative first exons identified by Rapid amplification of cDNA ends (RACE)-PCR. The first, exon 1I, starts approximately $700 \mathrm{bp}$ downstream of the splice donor site of the longest form of exon $1 \mathrm{~A}, 1 \mathrm{~A} 3$, considerably extending the known distal promoter region with a region containing conserved transcription factor-binding sites as well as a potential glucocorticoid response element (GRE) that differs from the consensus GRE in only two positions. The second, exon $1 \mathrm{~J}$, is part of the proximal promoter region and resides between exons 1D and 1E. Since this has been determined by quantitative real-time reverse transcriptase (RT)-PCR, exon $1 \mathrm{I}$ is used foremost in cells of the T-lymphocyte lineage. In the T-ALL cell line CEM-C7H2, which is sensitive to glucocorticoid-induced apoptosis, transcripts containing alternative first exons from the distal as well as the proximal promoter regions were markedly autoinduced by glucocorticoid treatment, with more pronounced relative induction in the distal promoter. Neither transcript was autoinduced in the related, resistant cell lines CEM-C1, and CEM-C7R5. In contrast, the glucocorticoid-sensitive PreB697 cell line strongly autoinduced transcripts from the proximal promoter, but not transcripts from the distal promoter, to relevant levels. Therefore, the autoinductive feedback loop implicated in glucocorticoid-induced apoptosis cannot universally rely on the distal promoter of the glucocorticoid receptor.
\end{abstract}

Journal of Molecular Endocrinology (2007) 38, 79-90

\section{Introduction}

Glucocorticoids (GC) induce highly diverse responses in different tissues such as brain, immune system, and metabolic organs (Sapolsky et al. 2000, Schimmer \& Parker 2006) to cope with stress events. This tissue diversity may partially be due to tissue-specific expression from multiple promoters, resulting in multiple alternative untranslated first exons, of the glucocorticoid receptor (GR). The GR gene (NR3C1, OMIM+138040) contains a presently undetermined number of untranslated first exons that are spliced to a common exon 2 (Strahle et al. 1992, Chen et al. 1999, McCormick et al. 2000, Breslin et al. 2001, Zhang et al. 2004, Turner \& Muller 2005). The resulting differences in $5^{\prime}$ untranslated regions may add a second level of regulation due to differing posttranscriptional treatment of the resulting mRNAs, potentially influencing mRNA processing, stability, export, and translation (Ayoubi \& Van De Ven 1996, Zhang et al. 2004). The alternative first exons identified thus far are located in two promoter regions, one proximal, spanning about $5 \mathrm{~kb}$ upstream of the translation start site, and the second distal, located more than $30 \mathrm{~kb}$ further upstream. For the human GR gene, nine untranslated exons have been published thus far (Breslin et al. 2001, Turner \& Muller 2005), 12 for the rat GR (McCormick et al. 2000, Zhang et al. 2004), and five for the mouse (Strahle et al. 1992, Chen et al. 1999). The splice donor sites terminating these first exons are highly conserved between man, mouse, and rat. Pronounced tissuespecific expression has been observed for both promoter regions. At the proximal promoter, rat exon $1_{7}$ was expressed at high levels in hippocampus (McCormick et al. 2000). Expression of certain distally located exons, termed 1A3 in man (Breslin et al. 2001), $1 \mathrm{~A}$ in mouse (Strahle et al. 1992), and $1_{1}$ in rat (McCormick et al. 2000), is limited to thymocytes, hematopoietic cell lines, and some regions of the brain.

Activated GR influences the expression of its own gene. Negative autoregulation of $G R$ expression has been observed in most tissues and cell lines (Kalinyak et al. 1987, Dong et al. 1988, Burnstein et al. 1991). Conversely, a few cell types, including thymocytes, some acute lymphoblastic leukaemia (ALL) cell lines, and primary ALL cells from patients, respond to GC with 
positive GR autoregulation (Eisen et al. 1988, Gomi et al. 1990, Obexer et al. 2001, Tonko et al. 2001, Yoshida et al. 2002, Schmidt et al. 2006), although no classical GC response element (GRE) has been identified in the known GR promoters. Interestingly, these cells are sensitive to GC-induced apoptosis. Concordantly, GC-resistant subclones of cell lines with this phenotype lost their ability to autoinduce GR after GC treatment (Kofler et al. 2003, Riml et al. 2004, Schmidt et al. 2006), and sensitivity for GC-induced apoptosis in GC-resistant Jurkat, and CCRF-CEM-sublines could be restored by GR overexpression (Helmberg et al. 1995, Geley et al. 1996, Schmidt et al. 2006). Because of these cell-specific apoptosis-inducing properties, GC are routinely used to treat lymphoblastic malignancies. Recent studies in cell lines suggest that distinct exons 1 may contribute more to GC sensitivity than others. It was shown that a high ratio of exon 1A3 to proximal located exons 1 increased the amount of GR-B protein, translated from the second start codon (Pedersen et al. 2004), which is more active in transactivation than the GR-A isoform (Yudt \& Cidlowski 2001). In GC-sensitive CEM-C7 cells, basal exon 1A3 levels were high and more strongly induced by GC than proximal first exons (Breslin et al. 2001, Pedersen \& Vedeckis 2003), further suggesting that promoter usage might account for sensitivity to GC-induced apoptosis. In contrast, a recent study of promoter usage in primary childhood ALL cells found no relation to GC sensitivity/resistance (Tissing et al. 2006).

In this study, we (i) searched for the presence of additional exons 1 in the human $G R$ gene, (ii) determined the expression levels of known $G R$ exons 1 in different human tissues, and (iii) addressed the question of whether usage of the distal GR promoters is a requirement for GC-induced cell death.

\section{Materials and methods}

\section{Cells}

The GC-sensitive CCRF-CEM-C7H2 cell line (StrasserWozak et al. 1995) and the two GC-resistant cell lines, CEM-C1 (Norman \& Thompson 1977) and CEM-C7R5 (Hala et al. 1996), have been described previously. GC-sensitive PreB697 c-ALL cells (Findley et al. 1982), recently renamed 'EU-3' by $\mathrm{H}$ W Findley (personal communication), were obtained from DSMZ (Braunschweig, Germany). The two non-hematopoietic adherent cell lines ONK2-H2B-GFP, an U2OS human osteosarcoma derivative (Geley et al. 2001) and HeLa Ohio human cervix carcinoma cells (ECACC 84121901), were provided by Dr Stephan Geley (Innsbruck Medical University, Austria). All cell lines were tested for, and found to be free of, mycoplasma infection and their authenticity was verified by DNA fingerprinting, as detailed previously (Parson et al. 2005). Suspension cells were maintained in RPMI 1640 medium (Cambrex Bio Science, Verviers, Belgium), and adherent cells in DMEM (Cambrex Bio Science). Media were supplemented with $10 \%$ FCS, $2 \mathrm{mM}$ L-glutamine, $100 \mathrm{U} / \mathrm{ml}$ penicillin, and $100 \mu \mathrm{g} / \mathrm{ml}$ streptomycin (all supplements from Invitrogen) at $37{ }^{\circ} \mathrm{C}$ and $5 \% \mathrm{CO}_{2}$. Human thymic tissue, obtained from thymi removed during pediatric cardiac surgery, was kindly provided by Dr Jan Wiegers (Innsbruck Medical University, Austria). Thymocytes were dissociated by injection of supplemented RPMI 1640 medium into the thymus tissue, which was then pressed through a sieve into culture medium. The thymocytes were maintained at a density of $3-7 \times 10^{6} \mathrm{cells} / \mathrm{ml}$.

\section{Apoptosis determination}

Apoptosis was determined by FACS analysis of propidium-iodide (PI)-treated permeabilized cells (Nicoletti et al. 1991). Briefly, $2-5 \times 10^{5}$ cells were pelleted, resuspended in $700 \mu \mathrm{l}$ Triton X-100/PI-staining solution $(50 \mu \mathrm{g} / \mathrm{ml}$ propidium-iodide, $0.1 \%$ sodium citrate, $0 \cdot 1 \%$ Triton X-100), maintained for a minimum of $6 \mathrm{~h}$ at $4{ }^{\circ} \mathrm{C}$ protected from light and analyzed with a FACScan cytometer (Becton Dickinson Biosciences, San Jose, CA, USA) using the CellQuest Pro software (Becton Dickinson Biosciences).

\section{RNA}

Total RNA from human tissues was obtained from Clontech or prepared from human cell lines and thymus tissue using TriReagent (MRC, Cincinnati, OH, USA), according to the manufacturer's protocol. The pellet obtained from $\sim 2 \times 10^{6}$ to $\sim 2 \times 10^{7}$ cells was resuspended in $1 \mathrm{ml}$ TriReagent. For the thymus, $90 \mathrm{mg}$ tissue was homogenized in a glass Teflon potter with $1 \mathrm{ml}$ TriReagent. After mixing with $200 \mu \mathrm{l}$ chloroform, RNA was precipitated from the aqueous supernatant by isopropanol.

\section{Rapid amplification of CDNA ends (RACE) PCR}

All primers are listed in Table 1. One microgram of CCRF-CEM-C7H2 total RNA or poly $\mathrm{A}^{+}$human placenta control RNA, $1 \mu \mathrm{l}$ of $10 \mu \mathrm{M}$ linker oligonucleotide (SMART III; Clontech), 0.5 $\mu$ random hexamer primers $(500 \mathrm{ng} / \mu \mathrm{l})$, and nuclease-free water to $5 \mu \mathrm{l}$ were incubated for $2 \mathrm{~min}$ at $72{ }^{\circ} \mathrm{C}$ and put on ice for $2 \mathrm{~min}$. After addition of $2 \mu \mathrm{l} 5 \times$ first-strand buffer, $1 \mu \mathrm{l}$ $20 \mathrm{mM}$ dithiothreitol (DTT), $1 \mu \mathrm{l}$ dNTP-Mix (each $10 \mathrm{mM}$ ), and $1 \mu \mathrm{l}$ PowerScript reverse transcriptase (Clontech), the solution was incubated for $1 \mathrm{~h}$ at $42{ }^{\circ} \mathrm{C}$. 
Table 1 Primer sequences

\begin{tabular}{|c|c|c|c|c|}
\hline & Primer & Sequence & localization & Paired primer(s)/probe \\
\hline \multicolumn{5}{|l|}{ Application } \\
\hline \multirow[t]{4}{*}{ RACE } & SMART III & 5'-AAGCAGTGGTATCAACGCAGAGTGGCCATTATGGCCGGG-3' & - & \\
\hline & $5^{\prime}$-PCR primer & 5'-AAGCAGTGGTATCAACGCAGAGT-3' & - & hGR 2R511, hGR 2RBA \\
\hline & hGR 2R511 & 5'-AGGAAAGGCTGATTTGGCCCTGCTGT-3' & Exon 2 & $5^{\prime}$-PCR primer \\
\hline & hGR 2RBA & 5'-CAGGAGTTAATGATTCTTTGGAGTCC-3' & Exon 2 & $5^{\prime}$-PCR primer \\
\hline \multirow[t]{5}{*}{ Hybridization } & HP1A1 & 5'-AGATCTTCTGATACCAAATCACTGGA-3' & Exon $1 \mathrm{~A} 1$ & \\
\hline & HP1A2 & 5'-ATGAGTGGGGAAGGATAGAAACA-3' & Exon $1 \mathrm{~A} 2$ & \\
\hline & HP11 & 5'-AGGAAGCTGCCAGAACCATCTAC-3' & Exon 11 & \\
\hline & HP1D & 5'-CTTAACGCCGCCCCAGA-3' & Exon $1 \mathrm{~F}$ & \\
\hline & HP1J & $5^{\prime}$-TGGACGCGGGCCCT-3' & Exon $1 \mathrm{~J}$ & \\
\hline \multirow{5}{*}{$\begin{array}{l}\text { Hybridization } \\
\text { and } \text { qPCR }^{1}\end{array}$} & hGR 2RBA & 5'-CAGGAGTTAATGATTCTTTGGAGTCC-3' & Exon 2 & hGR 1BF/hGR FAM 1 B2 \\
\hline & hGR 2R & 5'-TTCTTTGGAGTCCATCAGTGAATATC-3' & Exon 2 & hGR 1CF/hGR FAM 1C2 \\
\hline & hGR 1CF & 5'-GGGAACTGCGGACGGTG-3' & Exon $1 \mathrm{C}$ & hGR 2R/hGR FAM 1C2 \\
\hline & hGR 1BF & 5'-TGCCGGCACGCGA-3' & Exon 1B & hGR 2RBA/hGR FAM 1B2 \\
\hline & hGR 1A3F & 5'-GCCTGGCTCCTTTCCTCAA-3' & Exon $1 \mathrm{~A} 3$ & $1 \mathrm{~A} 3 \mathrm{Rq} / 1 \mathrm{~A} 3 \mathrm{Sq}$ \\
\hline \multirow[t]{14}{*}{$\mathrm{qPCR}^{1}$} & $1 \mathrm{IFq}$ & $5^{\prime}$-AAGGAAGGAGAGCAGTCAGGAA-3' & Exon 11 & 1A3Rq/1A3Sq \\
\hline & 1DFq & 5'-AAATCATAATCTGTGCCGCACA-3' & Exon 1D & $1 \mathrm{~A} 3 \mathrm{Rq} / 1 \mathrm{~A} 3 \mathrm{Sq}$ \\
\hline & $1 \mathrm{JFq}$ & $5^{\prime}$-AACTTGGACGCGGGCC-3' & Exon $1 \mathrm{~J}$ & $1 \mathrm{~A} 3 \mathrm{Rq} / 1 \mathrm{~A} 3 \mathrm{Sq}$ \\
\hline & 1FFq2 & $5^{\prime}$-CTGGAGAAACTCGGTGGCC-3' & Exon $1 \mathrm{~F}$ & $1 \mathrm{~A} 3 \mathrm{Rq} / 1 \mathrm{~A} 3 \mathrm{Sq}$ \\
\hline & $1 \mathrm{~A} 3 \mathrm{Rq}$ & 5'-САТСАСАТСТССССТСТССТG-3' & Exon 2 & $\begin{array}{l}\text { hGR 1A3F, 1FFq2, 1IFq, } \\
\text { 1JFq, 1DFq/1A3Sq }\end{array}$ \\
\hline & hGR FAM 1 C2 & 5' FAM-CGAGCGGCTCCTCTGCCAGAGT-TAMRA 3' & Exon $1 \mathrm{C} / 2$ & hGR $1 C F$, hGR $2 R$ \\
\hline & hGR FAM 1B2 & 5' FAM-CCCGGGCCCAAATTGATATTCACTG-TAMRA $3^{\prime}$ & Exon $1 \mathrm{~B} / 2$ & hGR 1BF, hGR 2RBA \\
\hline & $1 \mathrm{~A} 3 \mathrm{Sq}$ & $5^{\prime}$ FAM-AGAAGAAAACCCCAGCAGTGTGCTTGC-TAMRA $3^{\prime}$ & Exon 2 & $\begin{array}{l}\text { hGR 1A3F, 1FFq2, 1IFq, } \\
\text { 1JFq, 1DFq, 1A3Rq }\end{array}$ \\
\hline & hGR1275F & 5'-GAACTTCCCTGGTCGAACAGTT-3' & Exon 2 & hGR1358R/hGR FAM \\
\hline & hGR1358R & 5'-GAGCTGGATGGAGGAGAGCTT- $3^{\prime}$ & Exon 3 & hGR1275F/hGR FAM \\
\hline & hGR FAM & $5^{\prime}$ FAM-TGGCTATTCAAGCCCCAGCATGAGA-TAMRA $3^{\prime}$ & Exon $2 / 3$ & hGR 1275F, hGR1358R \\
\hline & $18 \mathrm{~S}$ fwd & 5'-CCATTCGAACGTCTGCCCTAT-3' & - & $18 \mathrm{~S} \mathrm{rev} / 18 \mathrm{~s}$ probe \\
\hline & $18 \mathrm{~S}$ rev & $5^{\prime}$-TCACCCGTGGTCACCATG-3' & - & $18 \mathrm{~S} \mathrm{fwd} / 18 \mathrm{~S}$ probe \\
\hline & $18 \mathrm{~S}$ probe & $5^{\prime}$ FAM-ACTTTCGATGGTAGTCGCCGTGCCT-Dabcyl 3' & - & $18 \mathrm{~S} \mathrm{fwd}, 18 \mathrm{~S} \mathrm{rev}$ \\
\hline
\end{tabular}

qPCR $^{1}$ : quantitative real-time reverse transcriptase (RT)-PCR.

First-strand cDNA corresponding to $40 \mathrm{ng}$ total RNA or $20 \mathrm{ng}$ control Poly $\mathrm{A}^{+}$RNA (Clontech), was PCR amplified with $200 \mu \mathrm{M}$ of each dNTP, $200 \mathrm{nM}$ genespecific reverse primer (hGR 2R511), $200 \mathrm{nM} \mathrm{5} 5^{\prime}$ PCR primer (Clontech), 2.5 or $3.5 \mathrm{mM} \mathrm{MgCl}_{2}, 5 \mu \mathrm{l} 10 \times$ Core Buffer (Brilliant Blue Core Reagent Kit; Stratagene Europe, Amsterdam, The Netherlands), and 2.5 U Sure Start Taq Polymerase (Stratagene Europe) at the following cycling parameters: $10 \mathrm{~min}$ at $95{ }^{\circ} \mathrm{C}, 30$ cycles of $15 \mathrm{~s}$ at $95{ }^{\circ} \mathrm{C}, 30 \mathrm{~s}$ at 61 or $65^{\circ} \mathrm{C}, 1 \mathrm{~min}$ at $72{ }^{\circ} \mathrm{C}$, and 1 cycle of $10 \mathrm{~min}$ at $72{ }^{\circ} \mathrm{C}$. PCRs were run on a Bio-Rad iCycler or an MWG Hybaid Thermocycler and the products analyzed on 2\% agarose gels. Reactions containing 2.5 and $3.5 \mathrm{mM} \mathrm{MgCl}_{2}$ amplified with an annealing temperature of 61 and $65{ }^{\circ} \mathrm{C}$ showed a clear band of about $500 \mathrm{bp}$ that was gel purified with QIAquick gel extraction kit (Qiagen) and reamplified with a nested gene-specific PCR primer (hGR 2RBA) and the $5^{\prime}$ PCR primer according to the above PCR amplification protocol using $2.5 \mathrm{mM} \mathrm{MgCl}_{2}$ and $60{ }^{\circ} \mathrm{C}$ annealing temperature. The resulting $\sim 250 \mathrm{bp}$ PCR product was cloned with the pGEM-T vector system (Promega). The experiment was repeated with CCRFCEM-C7H2 cells treated for $8 \mathrm{~h}$ with $10^{-7} \mathrm{M}$ dexamethasone and some technical modifications. For PCR amplification, the above protocol with $3.5 \mathrm{mM} \mathrm{MgCl}_{2}$ and an annealing temperature of $68{ }^{\circ} \mathrm{C}$ was applied.
PCR products were cloned without further purification into pGEM-T vector. To eliminate clones with known hGR exons 1, replica copies of the resulting colonies were differentially hybridized with ${ }^{32} \mathrm{P}$-labeled hGR exon 2 and hGR exons 1 oligodeoxynucleotides (ODNs). Clones corresponding to potentially novel exons 1 were grown, and the plasmids were purified with the Wizard Plus Minipreps DNA purification system (Promega) and sequenced (MWG, Ebersberg, Germany).

\section{Quantitative real-time RT-PCR}

First-strand cDNA was synthesized from $500 \mathrm{ng}$ total RNA in $20 \mu \mathrm{l}$ using random hexamer primers (Promega) and the Superscript II Reverse Transcriptase RNAse $\mathrm{H}^{-}$Kit (Invitrogen) according to the manufacturer's protocol.

PCR amplification was performed using the TaqMan assay (Applied Biosystems, Foster City, CA, USA). $\mathrm{C}_{\mathrm{T}}$ values of the target gene were normalized to the corresponding $18 \mathrm{~S}$ RNA $\mathrm{C}_{\mathrm{T}}$ values. Mean normalized expression (MNE) was calculated by the method described by Muller et al. (2002), which is a modified comparative $\mathrm{C}_{\mathrm{T}}$-method (User Bulletin \#2; Applied Biosystems) that accounts for amplification efficiencies. 
To quantify hGR exons 1 , the amplicon was positioned at the exon 1/exon 2 boundary, and for total GR at the exon 2/exon 3 boundary. Primers and TaqMan probes were designed with the Primer Express Software (Applied Biosystems). The TaqMan probes contained 6-carboxy-fluorescein (FAM) at the $5^{\prime}$ end and 6-carboxy- $N, N, N^{\prime}, N^{\prime}$-tetramethyl-rhodamine (TAMRA) at the $3^{\prime}$ end; only the $18 \mathrm{~S}$ RNA probe contained the quencher 4-(4'-dimethylaminophenylazo) benzoic acid (DABCYL) at the $3^{\prime}$ end. Primers and probes were obtained from MWG (Ebersberg, Germany) or Microsynth (Balgach, Switzerland), and the sequences are listed in Table 1. The probes for measuring total hGR, exons 1C, and 1B straddled the exon/exon boundary, and all remaining hGR exons were analyzed using a probe in exon 2. First-strand cDNA was PCR amplified using the Brilliant Blue Core Reagent Kit (Stratagene Europe). Each $25 \mu \mathrm{l}$ amplification reaction contained $2.5 \mu \mathrm{l}$ cDNA (corresponding to approximately $20 \mathrm{ng}$ RNA), $700 \mathrm{nM}$ forward primer, $700 \mathrm{nM}$ reverse primer, $250 \mathrm{nM}$ TaqMan probe (100 nM TaqMan probe for $18 \mathrm{~S}$ amplification), $2.5 \mu \mathrm{l} 10 \times$ Core buffer, $2.5 \mathrm{mM} \mathrm{MgCl}_{2}$, $0.2 \mathrm{mM}$ of each dNTP, $0.6 \mathrm{nM}$ reference dye and $1.25 \mathrm{U}$ Sure Start Taq. Reactions were carried out in triplicate in 96-well plates with the ABI Prism 7700 Sequence Detection system (Applied Biosystems) in a two-step amplification protocol: $10 \mathrm{~min}$ at $95{ }^{\circ} \mathrm{C}, 30$ cycles of $15 \mathrm{~s}$ at $95{ }^{\circ} \mathrm{C}$, and $1 \mathrm{~min}$ at $60{ }^{\circ} \mathrm{C}$. Data were analyzed with the Sequence Detection Software (Applied Biosystems).

\section{Sequences and software}

Human GR (NR3C1) promoter sequences (4552 bp distal, 5163 bp proximal) were extracted from the Homo sapiens chromosome 5 genomic contig NT_029289, gi 37550092 (last update 29-Aug-2006). The region complement (3943329.3948491) corresponds to the proximal $h G R$ promoter (translation initiation codon ATG is at position 3943340), the region complement $(3 \overline{9} 75640.3980191)$ corresponds to the distal $h G R$ promoter.

X66367 (Strahle et al. 1992) contains the mouse $G R$ $(\mathrm{Nr} 3 \mathrm{c} 1)$ proximal promoter sequence, the distal promoter sequence $(4550 \mathrm{bp})$ was obtained from Mus musculus chromosome 18 genomic contig NT_039674, gi 94404691 (last update 28-Apr-2006), region complement (36643735.36648284). The GR translation initiation codon ATG is at position 36613206 on the complementary strand of this chromosome contig.

The corresponding rat sequences are AJ271870 (McCormick et al. 2000) for the proximal GR (Nr3c1) promoter and $4665 \mathrm{bp}$ distal promoter sequence, extracted from Rattus norvegicus chromosome 18 genomic contig NW_047512, gi 62664370 (last update 22-Jun-2006), region complement (1160301.1164965).
The position of the rat GR translation initiation codon ATG is 1127464 on the complementary strand of this contig.

NNSPLICE 0.9 (Reese et al. 1997) is available at http://www.fruitfly.org/seq_tools/splice.html MatInspector is available at http://www.genomatix.de/

\section{Results}

\section{RACE-PCR on CCRF-CEM-C7H2 RNA revealed two novel hGR exons 1 , termed $1 \mathrm{I}$ and $1 \mathrm{~J}$}

To identify the hGR exons 1 expressed in the GC-sensitive T-ALL cell line CCRF-CEM-C7H2, RACEPCR was performed on total RNA from untreated and GC-treated ( $8 \mathrm{~h}$ with $10^{-7} \mathrm{M}$ dexamethasone) cells as detailed in Materials and methods. RACE products were ligated into the pGEM $T$ vector and screened for the presence of known alternative first exons with ${ }^{32} \mathrm{P}$ labeled oligonucleotide probes specific for hGR exons 2 and 1 A1, A2, A3, B, and C (Breslin et al. 2001). Sequencing plasmid inserts containing exon 2, but none of the tested first exons, revealed two novel first exons, termed 1I and $1 \mathrm{~J}$, in addition to the recently published exon 1F (Turner \& Muller 2005) and some scrambled sequences. Spatial relations between the novel and previously described exons 1 are shown in Fig. 1. Exon 1I maps to the distal promoter region downstream of exons 1A3, $1 \mathrm{~J}$ to the proximal promoter region. As detailed in Table 2, exons $1 \mathrm{~A} 3$ and $1 \mathrm{C}$ were predominant among the RACE-PCR products, followed in frequency by exons $1 \mathrm{~B}, 1 \mathrm{I}, 1 \mathrm{~F}$, and $1 \mathrm{~J}$.

\section{Basal expression levels of alternative first exons in tissues and cell lines: distal exon 11 is expressed predominantly in the T-cell lineage}

To determine the tissue-dependent usage of the newly identified versus previously known exons, we performed quantitative real-time RT-PCR on total GR (exon 2/exon 3 boundary), all alternative first exons detected by our RACE-PCR and exon 1D. We assayed total RNA from a panel of tissues and a number of GC-sensitive and -resistant cell lines. Mean normalized expression levels (MNE) are shown in Fig. 2.

The newly identified proximal exon, 1J, was expressed at significantly higher levels in cultured cells than in tissues. Marked expression of exon 1D was found in testis. Compared with the other first exons, upstream exon 1I showed an expression pattern similar to that of exon 1A3. Among the tissues assayed, the highest levels were reached in the thymus. Comparing different CCRF CEM sublines, basal expression levels of the distally located exons 1I and 1A3 showed some correlation with GC sensitivity. While expression levels of proximally 


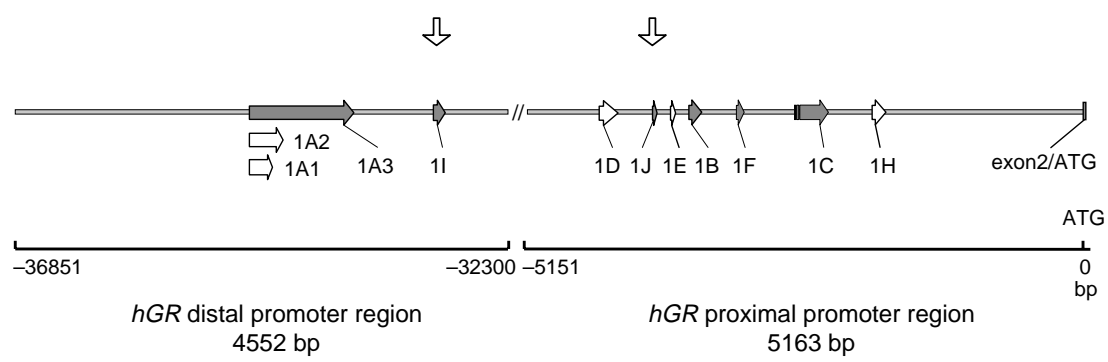

Figure 1 Mapping of newly identified exons $1 \mathrm{I}$ and $1 \mathrm{~J}$ to the $h G R$. Published exons $1 \mathrm{C}$ (Zong et al. 1990), 1A1, 1A2, 1A3, 1B (Breslin et al. 2001), 1D, 1E, 1F, and 1H (Turner \& Muller 2005) are indicated. Filled arrows mark exons 1 that could be detected by $5^{\prime}$ RACE in total RNA of CCRF-CEM-C7H2 cells. The sequence of the RACE product corresponding to exon $1 \mathrm{~J}$ is (-3993) ACCGGGAACTTGGACGCGGGCCCTGGCCGGGGTGGAAGAAGAG $(-3951)$, the respective sequence of 11 is shown in Fig. 4.

located exons in resistant CEM-C1 and CEM-C7R5 cells were $28-70 \%$ of those in sensitive CEM-C7H2 cells, the corresponding values were $6-35 \%$ for the two distally located first exons. Specifically, the expression levels of exon 1I in CEM-C7H2 were about sevenfold higher than in CEM-C1 cells, and 1A3 levels differed by a factor of about 3 between the two cell lines. There was also a difference in 1I levels between the two GC-resistant cell lines, CEM-C1, which expresses functional GR at a low level, and CEM-C7R5, which is deficient in ligand binding (Fig. 2). Interestingly, very low basal expression levels of exons 1I and 1A3 were found in GC-sensitive PreB697 cells.

\section{Glucocorticoid regulation of alternative first exons}

As detailed in the introduction, there is growing evidence for correlation of GC sensitivity and GR autoupregulation after GC treatment. To further address this issue, we analyzed the CCRF-CEM T-ALL and the PreB697 B-ALL model for changes in expression of total GR and the seven exons 1A3, 1B,
$1 \mathrm{C}, 1 \mathrm{D}, 1 \mathrm{~F}, 1 \mathrm{I}$, and $1 \mathrm{~J}$ after treatment with $10^{-7} \mathrm{M}$ dexamethasone using quantitative real-time RT-PCR with 18S RNA as reference. Total GR and all proximal alternative first exons were markedly induced by GC in the two sensitive cell lines, CEM-C7H2 and PreB697, but not at all or only slightly in GC-resistant CEM-C1 and CEM-C7R5 cells (Fig. 3). In contrast, we observed a marked difference in GC regulation at the distal promoters between the two sensitive cell lines. Distally located exons 1I and 1A3 were strongly induced in CEM-C7H2 cells, but negligibly in PreB697 cells (Fig. 3).

\section{In silico splice site prediction in human, mouse, and rat GR promoter regions}

Some of the previously known human exons have exact correlations in mouse and rat. To look for potential additional human splice sites and to determine whether exons $1 \mathrm{I}$ and $1 \mathrm{~J}$ might also be used in mouse and rat, we analyzed the proximal and the distal $G R$ promoter regions of man, mouse, and rat for potential splice sites

Table 2 Summary of the two RACE experiments

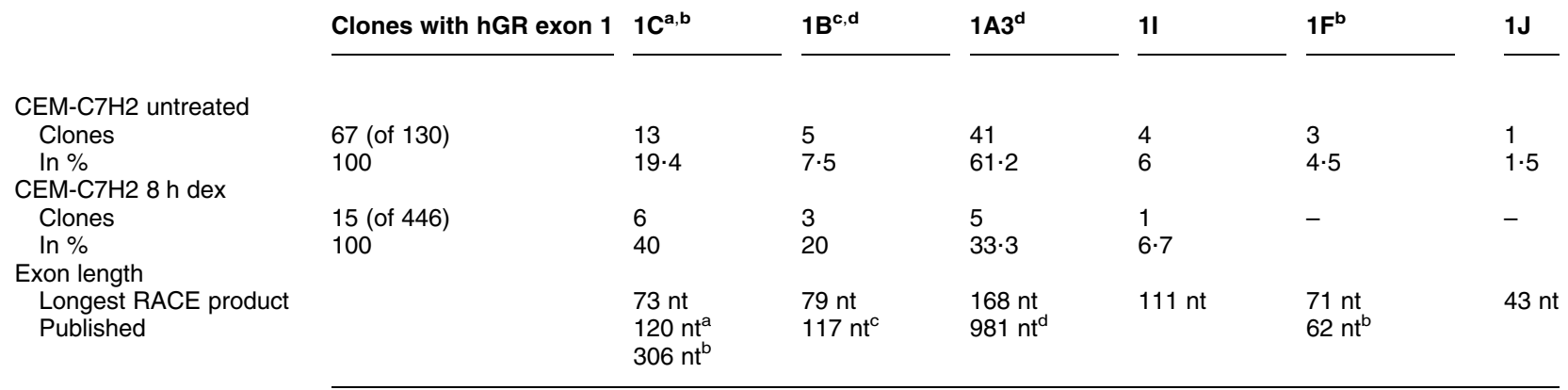

RACE products from untreated CEM-C7H2 cells were purified from the gel and reamplified with nested primers prior to cloning in pGEM-T vector. RACE products from GC-treated cells ( $8 \mathrm{~h}$ with $10^{-7} \mathrm{M}$ dexamethasone, dex) were cloned without further purification or amplification.

aZong et al. 1990.

${ }^{\mathrm{b}}$ Turner \& Muller (2005).

'Nunez \& Vedeckis (2002).

${ }^{\mathrm{d}}$ Breslin et al. (2001). 

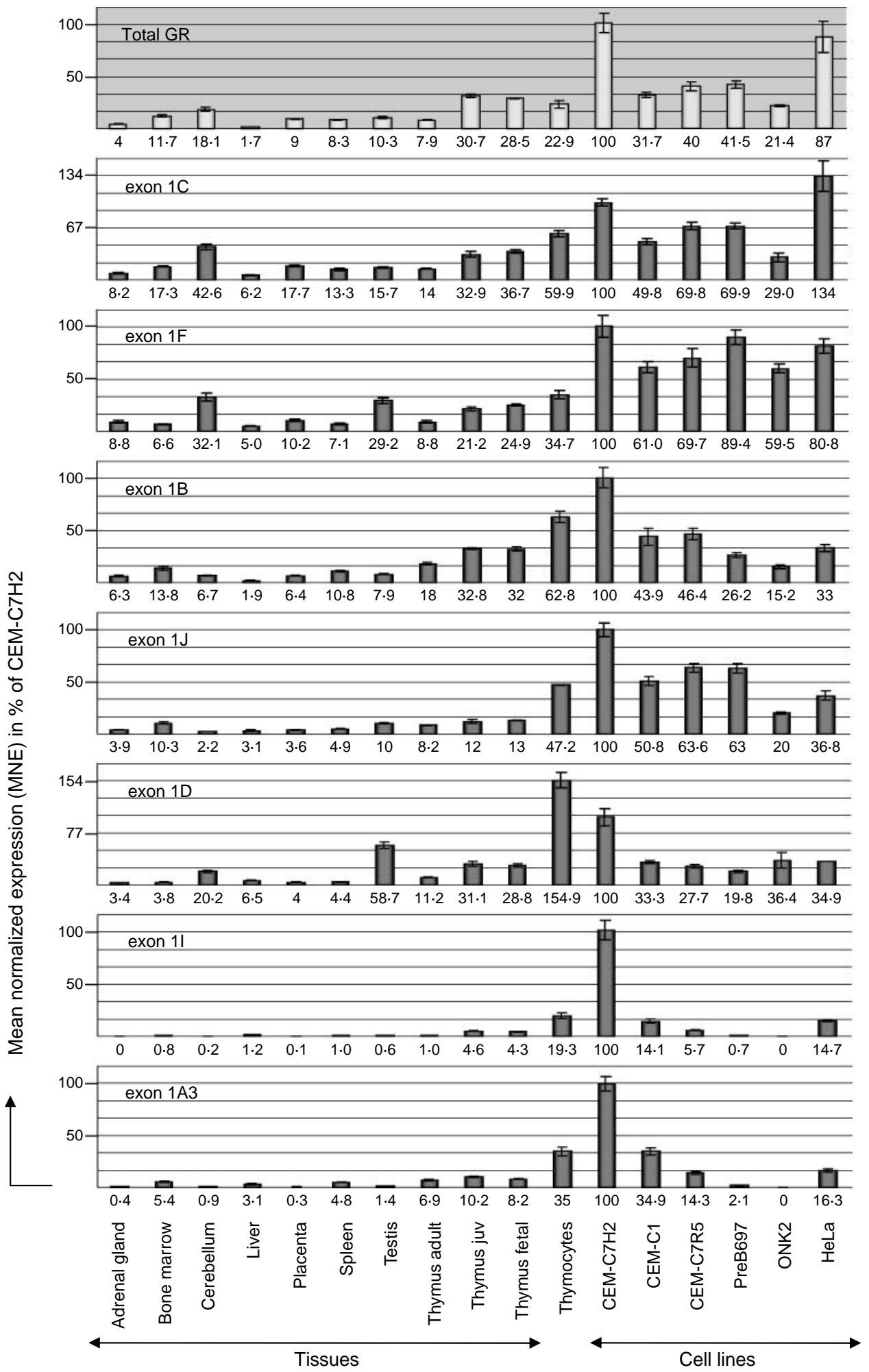

Figure 2 Mean normalized expression (MNE) values of total hGR and seven transcripts containing alternative hGR exons. Normalization refers to 18S RNA in all human cell lines and tissues, calculated with consideration of amplification efficiencies according to Muller et al. (2002). Expression levels as a percentage of CEM-C7H2 MNE are indicated at the bottom of the bars. 

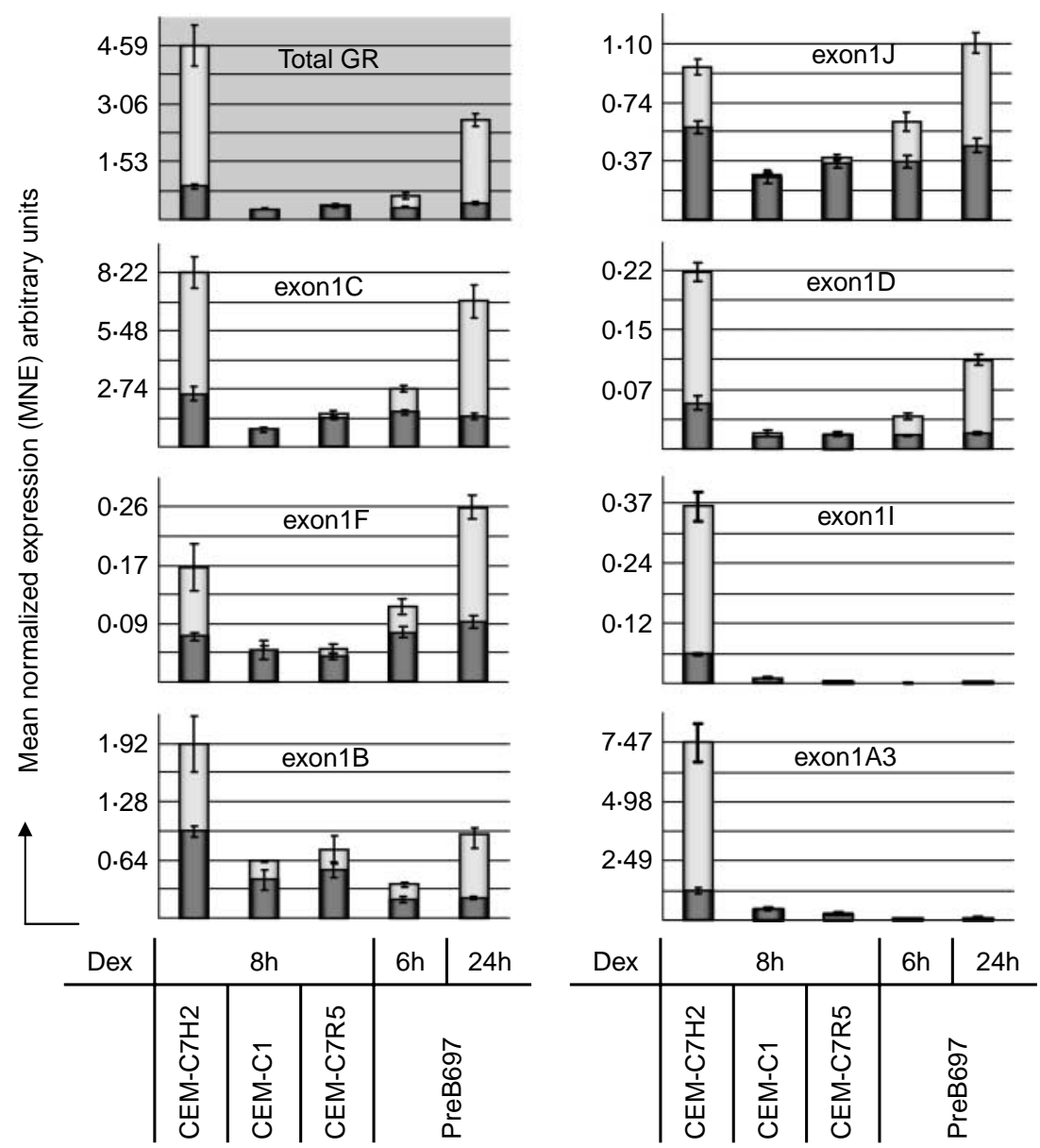

Figure 3 Glucocorticoid responsiveness of individual alternative first exons. Basal (filled bars) and induced (open bars) mean normalized expression (MNE) levels of total hGR and transcripts containing the indicated alternative first exons were determined by quantitative real-time RT-PCR in GC-sensitive CEM-C7H2 and PreB697, and GC-resistant CEM-C1 and CEM-C7R5 cells. Cells were induced with $10^{-7} \mathrm{M}$ dexamethasone (Dex) for the indicated durations; all expression data were normalized to 18S RNA.

using NNSPLICE 0.9 (Reese et al. 1997) and aligned them using the Align X software of the Vector NTI suite (Invitrogen). Aligned splice sites predicted by the algorithm are summarized in Table 3. Purely sequence-based predictions for the human promoter included scores of $0 \cdot 94,0 \cdot 96$, and $1 \cdot 0$ for known exons 1A3, 1B, and 1C respectively, which were present with high frequency in our RACE clones. For the newly identified exons described here, the actual splice sites were predicted with a score of 0.77 for $1 \mathrm{~J}$ and a perfect score of 1.0 for $1 \mathrm{I}$. The splice site of the recently reported exon 1F (Turner \& Muller 2005), which we also found in our RACE, was predicted with a score of $0 \cdot 49$. Another splice site, predicted with a score of $0 \cdot 94$, corresponds to that of the recently reported exon 1D (Turner \& Muller 2005). A total of six additional splice sites (1P1-1P6, Table 3), five in the distal and one in the proximal promoter, were predicted in the human sequence, and remain to be experimentally confirmed. Out of these sites, 1P3 in the distal and 1P6 in the proximal promoter had promising correlates in both mouse and rat.

\section{Discussion}

Our search for additional promoters/first exons of the human GR utilized RACE-PCR to identify three exons that could be verified by intron-spanning real-time PCR. One, exon 1F, was reported by Turner \& Muller (2005) during the progress of our work, and herein we report two other, previously unknown, exons: $1 \mathrm{~J}$ in the proximal and 1I in the distal promoter region. This increases the number of known alternative first exons to 11 , similar to the present number (12) in the rat $G R$ gene (McCormick et al. 2000, Zhang et al. 2004), 
Table 3 Score of aligned splice sites in human, mouse, and rat GR promoter regions

Splice donor site $h G R$ gene

Position relative to hGR ATG

Calculated score (NNSPLICE 0.9)

\begin{tabular}{|c|c|c|c|c|}
\hline & & Human & Mouse & Rat \\
\hline & -36851 to -32300 & & & \\
\hline TAAAACGATAGT & -36010 & 0.58 & 0.32 & $0 \cdot 10$ \\
\hline ACCTTAGAAGGT & -34462 & 0.53 & 0.37 & 0.07 \\
\hline CAGAAAGAGGGT & -34365 & 0.99 & No spl. site & No spl. site \\
\hline GAGAAGGAAGGT & -33693 & 0.94 & $1 \cdot 00$ & 1.00 \\
\hline GCTGGGTAAAGT & -33654 & 0.97 & $<0.01$ & 0.06 \\
\hline TCACTCAGAGGT & -33614 & 0.67 & $0 \cdot 76$ & $0 \cdot 81$ \\
\hline TATTCAGCAAGT & -33470 & $0 \cdot 88$ & $0 \cdot 79$ & $<0.01$ \\
\hline CATGAGAGAGGT & -32880 & $1 \cdot 00$ & No spl. site & 0.08 \\
\hline TACAGATCAGGT & $\begin{array}{l}-32755 \\
-5151 \text { to }+12\end{array}$ & 0.96 & 0.03 & 0.03 \\
\hline GCCGCACAAGGT & -4311 & 0.94 & 0.72 & $0 \cdot 21$ \\
\hline & -4247 & No spl. site & $0 \cdot 11$ & 0.44 \\
\hline GGAAGAAGAGGT & -3951 & 0.77 & 0.55 & 0.55 \\
\hline TCCTTCGAGTGT & -3780 & $<0.01$ & 0.32 & $<0.01$ \\
\hline CGGGCCCAAAGT & -3537 & 0.96 & 0.38 & 0.38 \\
\hline GAGAGACCAGGT & -3147 & 0.49 & $0 \cdot 15$ & $0 \cdot 15$ \\
\hline TCACCAACAGGT & -2946 & 0.08 & $0 \cdot 14$ & 0.14 \\
\hline GACGGATTCTGT & -2685 & $<0.01$ & $0 \cdot 10$ & $0 \cdot 10$ \\
\hline TCTGCCAGAGGT & -2372 & $1 \cdot 00$ & 0.97 & 0.97 \\
\hline AACTCAACAGGT & -1763 & 0.53 & 0.53 & 0.53 \\
\hline AAATTTGGAGGT & -575 & 0.93 & 0.96 & 0.96 \\
\hline
\end{tabular}

Exon (predicted exon)
Distal GR promoter
Predicted h $1 \mathrm{P} 1$
h $1 \mathrm{~A} 1$
h $1 \mathrm{~A} 2$
h $1 \mathrm{~A} 3 / \mathrm{m} 1 \mathrm{~A} / \mathrm{r} 1_{1}$
Predicted h $1 \mathrm{P} 2$
Predicted h $1 \mathrm{P3}$
Predicted h $1 \mathrm{P} 4$
h $1 \mathrm{l}$
Predicted h $1 \mathrm{P} 5$
Proximal GR promoter
h $1 \mathrm{D}$
r $1_{4}$
h $1 \mathrm{~J}$
h $1 \mathrm{E} / \mathrm{m} 1 \mathrm{D} / \mathrm{r} 1_{5}$
h $1 \mathrm{~B} / \mathrm{m} 1 \mathrm{~B} / \mathrm{r} 1_{6}$
h $1 \mathrm{~F} / \mathrm{r} 1_{7}$
r 18
r $1_{9}$
h $1 \mathrm{C} / \mathrm{m} 1 \mathrm{C} / \mathrm{r} 1_{10}$
h $1 \mathrm{H} / \mathrm{m} 1 \mathrm{E} / \mathrm{r} 1_{11}$
Predicted h $1 \mathrm{P} 6$

Human $(\mathrm{h})$, mouse $(\mathrm{m})$, and rat $(\mathrm{r})$ proximal and distal GR promoter sequences were analyzed with NNSPLICE 0.9. (Reese et al. 1997) and aligned using ALIGN X (Vector NTI Suite 6, Invitrogen). Aligned hGR splice sites that correspond to a known exon 1 of the three species or have a score $>0.4$ in the human gene (predicted exons) are shown.

although thus far no direct mouse or rat correlates of exons 1 I or $1 \mathrm{~J}$ have been reported.

Is there a possibility that mouse or rat use these exons? Comparing the splice sites of the two newly identified human exons with predicted splice sites in mouse and rat, the splice donor site of proximal exon 1J seemed to be conserved, with scores of 0.55 in both mouse and rat. Further arguing in favor of a functional role of exon 1J in rodents is the fact that the region between exon $1 \mathrm{~J}$ and the upstream exon $1 \mathrm{D}$ is conserved, showing $68 \%$ identity between man, mice, and rat.

For distal exon 1I, the software predicted a splice site with a weak score of 0.08 in rat, but no splice site in the mouse. Alignment of the promoter/exon 1I (P/E1I) region, defined as the $702 \mathrm{bp}$ sequence between the exon 1A3 splice site and the start of exon 1I, in man, mouse, and rat (Fig. 4) revealed low overall homology (about 50\%) with one exception. The first $250 \mathrm{bp}$ of this region, $\sim 75 \%$ conserved between man and rodents (disregarding a microsatellite in the rat), contain conserved transcription factor-binding motifs like E4BP4 (Cowell et al. 1992), GATA (Ko \& Engel 1993), IRF3 (Lin et al. 2000), ISRE (Levy et al. 1988), OCT1 (Groenen et al. 1992), Pit1 (Mangalam et al. 1989), and COMP1 (Funk \& Wright 1992). While it seems unlikely that mouse or rat uses an exact correlate of $1 \mathrm{I}$, a regulatory role of the $\mathrm{P} / \mathrm{E} 1 \mathrm{I}$ region in these species is suggested by these conserved elements between $1 \mathrm{~A} 3$ and $1 \mathrm{I}$.

The distal promoter region has thus far been defined by the three forms of exon $1 \mathrm{~A}$, about $34 \mathrm{~kb}$ upstream of the common exon 2 (Breslin et al. 2001). Multiple gene regulatory elements were analyzed in terms of 12 footprints within and upstream of exon 1A3 (Geng \& Vedeckis 2004). Our results indicate that the distal promoter region has to be markedly extended downstream to include alternative first exon 1I. In addition to the conserved-binding elements mentioned above, this region contains a predicted GRE with the sequence GGTAAAnnnAGTTCT, which differs in only two positions from the classical consensus GRE, GGTACAnnnTGTTCT (Beato et al. 1989). If functional, this GRE may be important in conjunction with the conserved E4BP4/NF-IL3A-binding site. As shown by Medh et al. (2003), E4BP4, which is repressive in most cell lines (Cowell et al. 1992, Wallace et al. 1997), but is transactivating in lymphoid cell lines (Zhang et al. 1995, Cowell 2002), is strongly induced by GC in sensitive CEM-C7 sublines, but not in resistant CEM-C1 sublines.

In a series of studies over the last few years, Vedeckis et al. have developed a model to explain the autoinductive GR feedback loop in cells prone to glucocorticoid apoptosis. The model consists of three elements. 


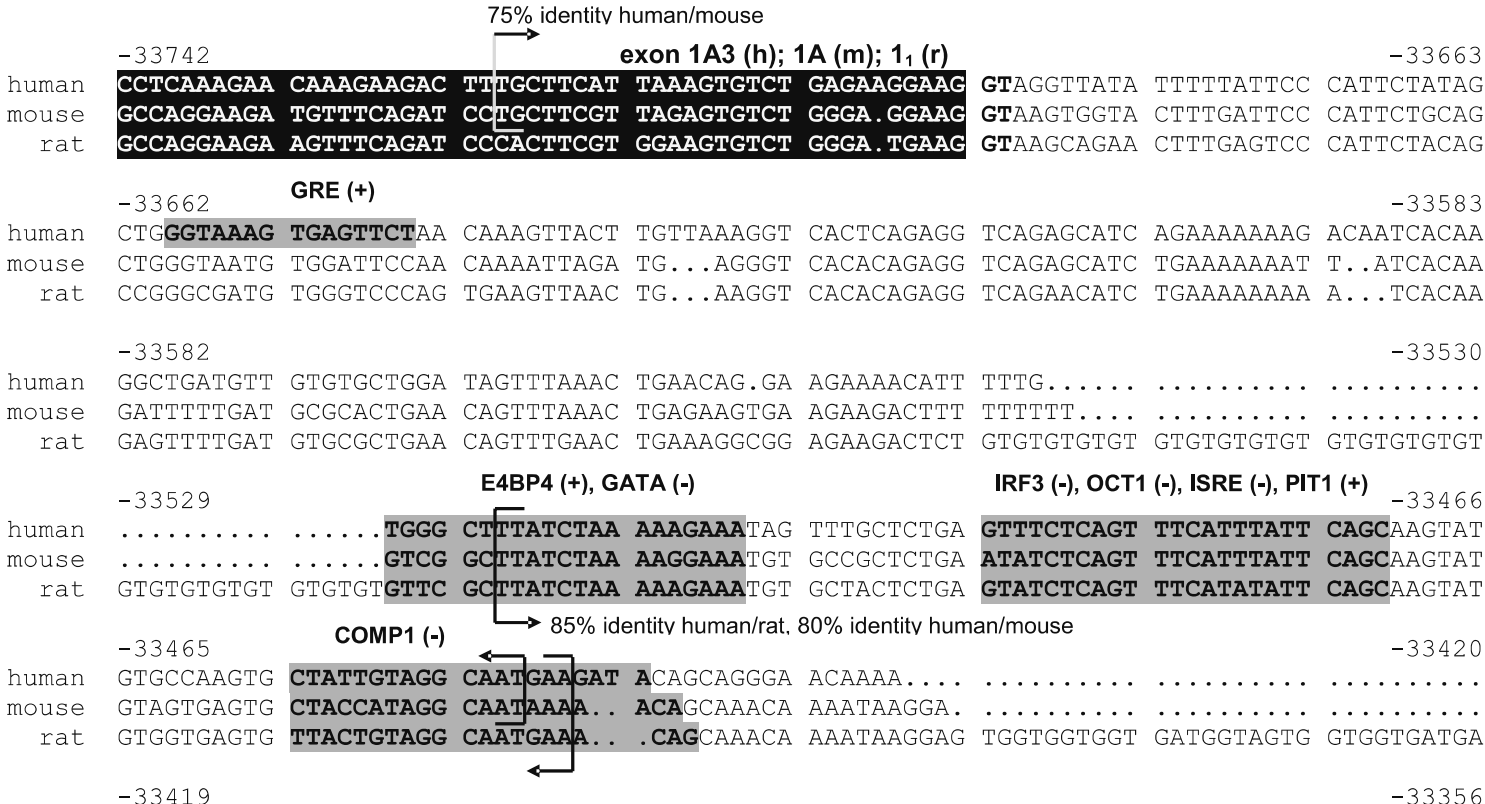

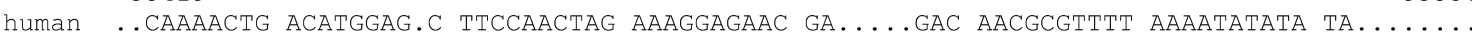
mouse ..CTAATGAG GCATGTATAC GTGTGTGTGT GTGTGTGTGT GT.....GTG TGTGTGTGTG TGTGTGTGTG TATGCCTGTG

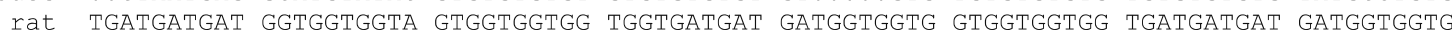

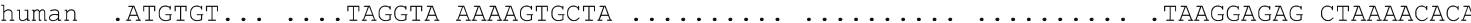
mouse TATGTGTCTC TGTGTATGTC TGTGTGTGTC . . . . . . . . . . . . ... . TATGTGTAT TTATGTGTGT rat GTGGTGGTGG TGGTGAtGAT GATGGTGGTG GTGGTGGTGG TGGTGGTGGT GGTGGTGGTG GTGTGTGTGT GTGTGTGTGT

$-33314$

$-32236$

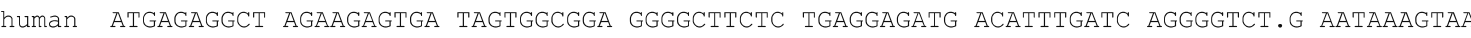
mouse GTGTGTGTGT . GATGTGACA TGTTAGGTAA AAAGTACCTT GAACAAAACC AAAACACAGC AgAGAACtAG AAAGGAATAG rat GTGTGTGTGT . GGTGTGACG TGCTAGGTGg AAAGTACCCT GAACAAAACC AAAACATAGC AAAGgACTAG AAAGGAATAG

$-32235$

$-33179$

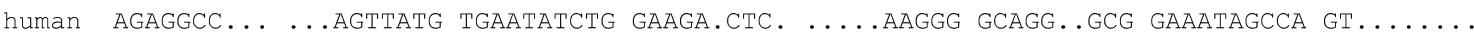
mouse AGGTGCCTTG TGTAGGTAGG CAACTATTGG GCAGAACTCT AAATAAAGGA GCAGACTGTG TAGTTGTCCA GGGACCCC.A rat GGGTACATTG TGTAGGGAgG CAACTGTTAA GCAGAGCCTT GAATAAAGAT GCAAACtACA TGTTTGTCTA GGGACCCCCA

human . AGAA .............AgGC CCTGAGGTAG GAAGGTGTGT GGCAAGTTTG AGGAAAAGGA AAGACAGTCT GACTGGAGCA

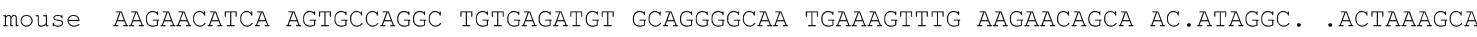

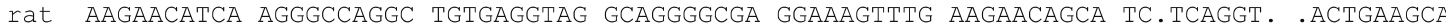

$-33110$

human AAGAGAACTG GAGCTGAgGC CATCAAGGCA GCCAGGAGCC AGGTGCAGAC TGGGCTTTGA CTCTGCCTGC AGg. GAGGAA mouse GAGAAACAGG GCAGAGATGA GATACAGGGA . CAAAGAGTT AGCTGG.GAg AGGGAC..AA CCCTGGCTGT GGCAGCAGGA rat GAGAAGCAGG GCAGAGATGA GACACAGGGA .CCAAGAGAC AGCTGG.GAg AGGGAC..gG CCCTAGCTGT GGCACCAGGA

-33031
human CTGCTGAAGG TTCCAAGCAA AGG... ACCG CCCTGACCTG CCTTAGGTTT GAACAGGATC CCTCTGGCTG GTGTGTGAAG mouse GAGCTGg.gG TATCACTGAT GGGTTTATGT CCAGGGCC.. ACTTAGGATC TCCTGGGATC TCTCTGGCTG GAG...GCAA

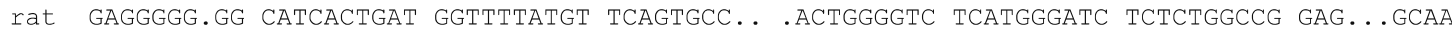

\begin{tabular}{|c|c|c|c|c|c|c|c|}
\hline & & & & & & & \\
\hline & АACTGT & AGATGGGCAA & GTGTGGAAGG & AAGGAGAGCA & TCAGGAAGC & $\mathrm{AACC}$ & GA \\
\hline & $\begin{array}{l}\text { GGCTCAGTGT } \\
\text { GGCTAAGTGT }\end{array}$ & ATC. . CACA & & & & & \\
\hline
\end{tabular}

Figure 4 Alignment of $h G R$ promoter/exon 11 region with the corresponding mouse and rat GR sequences. Dots indicate gaps, not identical nucleotides. Exon sequences are indicated by white font on dark background. $5^{\prime}$-Ends of four sequenced exon 1 I RACE-PCR products are underlined, the second underline representing two independent products. Regions highly conserved between man-mouse and man-rat respectively, are indicated by brackets with arrows. A predicted GRE and transcription factor-binding sites conserved between all three species are shaded grey with + or - indicating strand orientation. 
The first element is a marked difference in glucocorticoid autoregulation of GR transcripts depending on the cellular background: transcripts containing all alternative first exons are induced by GC in CEM-C7 cells, but downregulated in IM-9 B-lymphoma cells (Breslin et al. 2001). This effect is most pronounced for distal exon 1A3 (Pedersen \& Vedeckis 2003).

Secondly, glucocorticoid regulation of 1A3 depends on a DNA element within 1A3 that can be bound by either c-Myb or c-Ets (PU.1). This site is adjacent to a non-consensus glucocorticoid-response element. In cells where c-Myb dominates over PU.1, 1A3 is autoinduced by GC, whereas in cells expressing mainly PU.1, 1A3 is autorepressed (Geng \& Vedeckis 2004, 2005).

The third element, Pedersen et al. (2004) hypothesize, may be a shift to a more active GR isoform caused by an upstream open reading frame in 1A3. The hGR exon 1A3 transcript contains an upstream open reading frame (uORF) with a termination codon that overlaps the start codon of the GR-A isoform. In human estrogen receptor $\alpha$, it was shown that UORFs that terminate close to the initiation codon of the main ORF have an inhibitory effect on translation (Kos et al. 2002). Analogously, translation of the hGR 1A3 uORF might impair translation initiation at the first hGR AUG and promote translation initiation at the second AUG, leading to a higher ratio of GR-B:GR-A isoforms. Since the GR-B isoform is transciptionally more active (Yudt \& Cidlowski 2001), transcripts originating from 1A3 could enhance the feedback loop by this mechanism.

Taken together, this model attributes the induction of apoptosis by GC mainly to the distal GR promoter, specifically to exon $1 \mathrm{~A} 3$, although its validity in childhood ALL has recently been questioned (Tissing et al. 2006).

As far as CEM-C7 cells are concerned, our results are generally compatible with this model. We find strong autoinduction of 1I-containing GR transcripts mirroring 1A3-containing transcripts. In addition, a similar uORF exists in 1I-containing transcripts as in 1A3-containing transcripts. This open reading frame starts at nt 49 of exon 1I, stops at nt 45 of hGR exon 2 , and codes for a peptide of 35 AA. The ORF overlaps the first hGR AUG (nt 14-16 of hGR exon 2) and terminates before the second hGR AUG, which is positioned at nt 92-94 of hGR exon 2. Therefore, point 3 of the model mentioned above might also pertain to exon $1 \mathrm{I}$.

However, our results in PreB697 cells raise a note of caution. Although PreB697 cells undergo apoptosis in response to GC, autoinduction of either exon from the distal promoter does not lead to relevant transcript levels. Instead, PreB697 cells induce all proximal exons to considerable levels, suggesting that induction of distal exon(s) may be the mechanism that induces apoptosis in T-cells, but is not a universal mechanism of inducing apoptosis by GC.

\section{Acknowledgements}

We thank Dr Stephan Geley for helpful discussions, Dr Ernst Werner for assistance with quantitative real-time PCR, Drs Jan Wiegers and Ilona Stec for kindly providing human thymic tissue and M Kat OcchipintiBender for editing the manuscript. This work was supported by the Austrian Research Fund (SFB-F021 and P18571 to RK and P16013 to AH) as well as by grants to AH from the Tyrolean Science Fund and the Tyrolean Cancer Society. The Tyrolean Cancer Research Institute is supported by the 'Tiroler Landeskrankenanstalten Ges.m.b.H. (TILAK)', the 'Tyrolean Cancer Society', various businesses, financial institutions, and the People of Tyrol. The authors declare that there is no conflict of interest that would prejudice the impartiality of this scientific work.

\section{References}

Ayoubi TA \& Van De Ven WJ 1996 Regulation of gene expression by alternative promoters. FASEB Journal 10 453-460.

Beato M, Chalepakis G, Schauer M \& Slater EP 1989 DNA regulatory elements for steroid hormones. Journal of Steroid Biochemistry 32 $737-747$.

Breslin MB, Geng CD \& Vedeckis WV 2001 Multiple promoters exist in the human GR gene, one of which is activated by glucocorticoids. Molecular Endocrinology 15 1381-1395.

Burnstein KL, Bellingham DL, Jewell CM, Powell-Oliver FE \& Cidlowski JA 1991 Autoregulation of glucocorticoid receptor gene expression. Steroids $\mathbf{5 6}$ 52-58.

Chen F, Watson CS \& Gametchu B 1999 Multiple glucocorticoid receptor transcripts in membrane glucocorticoid receptor-enriched S-49 mouse lymphoma cells. Journal of Cellular Biochemistry 74 418-429.

Cowell IG 2002 E4BP4/NFIL3, a PAR-related bZIP factor with many roles. Bioessays 24 1023-1029.

Cowell IG, Skinner A \& Hurst HC 1992 Transcriptional repression by a novel member of the bZIP family of transcription factors. Molecular and Cellular Biology 12 3070-3077.

Dong Y, Poellinger L, Gustafsson JA \& Okret S 1988 Regulation of glucocorticoid receptor expression: evidence for transcriptional and posttranslational mechanisms. Molecular Endocrinology 2 $1256-1264$.

Eisen LP, Elsasser MS \& Harmon JM 1988 Positive regulation of the glucocorticoid receptor in human T-cells sensitive to the cytolytic effects of glucocorticoids. Journal of Biological Chemistry $\mathbf{2 6 3}$ 12044-12048.

Findley HW Jr, Cooper MD, Kim TH, Alvarado C \& Ragab AH 1982 Two new acute lymphoblastic leukemia cell lines with early B-cell phenotypes. Blood 60 1305-1309.

Funk WD \& Wright WE 1992 Cyclic amplification and selection of targets for multicomponent complexes: myogenin interacts with factors recognizing binding sites for basic helix-loop-helix, nuclear factor 1, myocyte-specific enhancer-binding factor 2, and COMP1 factor. PNAS 89 9484-9488.

Geley S, Hartmann BL, Hala M, Strasser-Wozak EM, Kapelari K \& Kofler R 1996 Resistance to glucocorticoid-induced apoptosis in 
human T-cell acute lymphoblastic leukemia CEM-C1 cells is due to insufficient glucocorticoid receptor expression. Cancer Research $\mathbf{5 6}$ 5033-5038.

Geley S, Kramer E, Gieffers C, Gannon J, Peters JM \& Hunt T 2001 Anaphase-promoting complex/cyclosome-dependent proteolysis of human cyclin A starts at the beginning of mitosis and is not subject to the spindle assembly checkpoint. Journal of Cell Biology 153 $137-148$.

Geng CD \& Vedeckis WV 2004 Steroid-responsive sequences in the human glucocorticoid receptor gene $1 \mathrm{~A}$ promoter. Molecular Endocrinology 18 912-924.

Geng CD \& Vedeckis WV 2005 c-Myb and members of the c-Ets family of transcription factors act as molecular switches to mediate opposite steroid regulation of the human glucocorticoid receptor 1A promoter. Journal of Biological Chemistry 280 43264-43271.

Gomi M, Moriwaki K, Katagiri S, Kurata Y \& Thompson EB 1990 Glucocorticoid effects on myeloma cells in culture: correlation of growth inhibition with induction of glucocorticoid receptor messenger RNA. Cancer Research 50 1873-1878.

Groenen MA, Dijkhof RJ, van der Poel JJ, van Diggelen R \& Verstege E 1992 Multiple octamer binding sites in the promoter region of the bovine alpha s2-casein gene. Nucleic Acids Research 20 4311-4318.

Hala M, Hartmann BL, Bock G, Geley S \& Kofler R 1996 Glucocorticoid-receptor-gene defects and resistance to glucocorticoid-induced apoptosis in human leukemic cell lines. Nucleic Acids Research 68 663-668.

Helmberg A, Auphan N, Caelles C \& Karin M 1995 Glucocorticoidinduced apoptosis of human leukemic cells is caused by the repressive function of the glucocorticoid receptor. EMBO Journal 14 452-460.

Kalinyak JE, Dorin RI, Hoffman AR \& Perlman AJ 1987 Tissue-specific regulation of glucocorticoid receptor mRNA by dexamethasone. Journal of Biological Chemistry 262 10441-10444.

Ko LJ \& Engel JD 1993 DNA-binding specificities of the GATA transcription factor family. Molecular and Cellular Biology 13 4011-4022.

Kofler R, Schmidt S, Kofler A \& Ausserlechner MJ 2003 Resistance to glucocorticoid-induced apoptosis in lymphoblastic leukemia. Journal of Endocrinology 178 19-27.

Kos M, Denger S, Reid G \& Gannon F 2002 Upstream open reading frames regulate the translation of the multiple mRNA variants of the estrogen receptor alpha. Journal of Biological Chemistry 277 37131-37138.

Levy DE, Kessler DS, Pine R, Reich N \& Darnell JE Jr 1988 Interferoninduced nuclear factors that bind a shared promoter element correlate with positive and negative transcriptional control. Genes and Development 2 383-393.

Lin R, Genin P, Mamane Y \& Hiscott J 2000 Selective DNA binding and association with the CREB binding protein coactivator contribute to differential activation of alpha/beta interferon genes by interferon regulatory factors 3 and 7. Molecular and Cellular Biology 20 6342-6353.

Mangalam HJ, Albert VR, Ingraham HA, Kapiloff M, Wilson L, Nelson C, Elsholtz H \& Rosenfeld MG 1989 A pituitary POU domain protein, Pit1 , activates both growth hormone and prolactin promoters transcriptionally. Genes and Development 3 946-958.

McCormick JA, Lyons V, Jacobson MD, Noble J, Diorio J, Nyirenda M, Weaver S, Ester W, Yau JL, Meaney MJ et al. $20005^{\prime}$-heterogeneity of glucocorticoid receptor messenger RNA is tissue specific: differential regulation of variant transcripts by early-life events. Molecular Endocrinology 14 506-517.

Medh RD, Webb MS, Miller AL, Johnson BH, Fofanov Y, Li T, Wood TG, Luxon BA \& Thompson EB 2003 Gene expression profile of human lymphoid CEM cells sensitive and resistant to glucocorticoid-evoked apoptosis. Genomics 81 543-555.

Muller PY, Janovjak H, Miserez AR \& Dobbie Z 2002 Processing of gene expression data generated by quantitative real-time RT-PCR.

Biotechniques 32 1372-1379.
Nicoletti I, Migliorati G, Pagliacci MC, Grignani F \& Riccardi C 1991 A rapid and simple method for measuring thymocyte apoptosis by propidium iodide staining and flow cytometry. Journal of Immunological Methods 139 271-279.

Norman MR \& Thompson EB 1977 Characterization of a glucocorticoid-sensitive human lymphoid cell line. Cancer Research 37 $3785-3791$.

Nunez BS \& Vedeckis WV 2002 Characterization of promoter 1B in the human glucocorticoid receptor gene. Molecular and Cellular Endocrinology 189 191-199.

Obexer P, Certa U, Kofler R \& Helmberg A 2001 Expression profiling of glucocorticoid-treated T-ALL cell lines: rapid repression of multiple genes involved in RNA-, protein- and nucleotide synthesis. Oncogene 20 4324-4336.

Parson W, Kirchebner R, Muhlmann R, Renner K, Kofler A, Schmidt S \& Kofler R 2005 Cancer cell line identification by short tandem repeat profiling: power and limitations. FASEB Journal 19 434-436.

Pedersen KB \& Vedeckis WV 2003 Quantification and glucocorticoid regulation of glucocorticoid receptor transcripts in two human leukemic cell lines. Biochemistry 42 10978-10990.

Pedersen KB, Geng CD \& Vedeckis WV 2004 Three mechanisms are involved in glucocorticoid receptor autoregulation in a human T-lymphoblast cell line. Biochemistry 43 10851-10858.

Reese MG, Eeckman FH, Kulp D \& Haussler D 1997 Improved splice site detection in Genie. Journal of Computational Biology 4 311-323.

Riml S, Schmidt S, Ausserlechner MJ, Geley S \& Kofler R 2004 Glucocorticoid receptor heterozygosity combined with lack of receptor auto-induction causes glucocorticoid resistance in Jurkat acute lymphoblastic leukemia cells. Cell Death and Differentiation 11 S65-S72.

Sapolsky RM, Romero LM \& Munck AU 2000 How do glucocorticoids influence stress responses? Integrating permissive, suppressive, stimulatory, and preparative actions. Endocrine Reviews 21 55-89.

Schimmer BP \& Parker KL 2006 Adrenocortical steroids. In Goodman and Gilman's The Pharmacological Basis of Therapeutics, 11 edn, pp 1593-1610. Eds L Brunton, J Lazo \& K Parker. New York: McGraw-Hill.

Schmidt S, Rainer J, Riml S, Ploner C, Jesacher S, Achmuller C, Presul E, Skvortsov S, Crazzolara R, Fiegl M et al. 2006 Identification of glucocorticoid-response genes in children with acute lymphoblastic leukemia. Blood 107 2061-2069.

Schmidt S, Irving JA, Minto L, Matheson E, Nicholson L, Ploner A, Parson W, Kofler A, Amort M, Erdel M et al 2006 Glucocorticoid resistance in 2 key models of acute lymphoblastic leukemia occurs at the level of the glucocorticoid receptor. FASEB Journal In press.

Strahle U, Schmidt A, Kelsey G, Stewart AF, Cole TJ, Schmid W \& Schutz G 1992 At least three promoters direct expression of the mouse glucocorticoid receptor gene. PNAS 89 6731-6735.

Strasser-Wozak EM, Hattmannstorfer R, Hala M, Hartmann BL, Fiegl M, Geley S \& Kofler R 1995 Splice site mutation in the glucocorticoid receptor gene causes resistance to glucocorticoid-induced apoptosis in a human acute leukemic cell line. Cancer Research $\mathbf{5 5}$ 348-353.

Tissing WJ, Meijerink JP, Brinkhof B, Broekhuis MJ, Menezes RX, den Boer ML \& Pieters R 2006 Glucocorticoid-induced glucocorticoid-receptor expression and promoter usage is not linked to glucocorticoid resistance in childhood ALL. Blood 108 1045-1049.

Tonko M, Ausserlechner MJ, Bernhard D, Helmberg A \& Kofler R 2001 Gene expression profiles of proliferating vs. G1/G0 arrested human leukemia cells suggest a mechanism for glucocorticoid-induced apoptosis. FASEB Journal 15 693-699.

Turner JD \& Muller CP 2005 Structure of the glucocorticoid receptor (NR3C1) gene $5^{\prime}$ untranslated region: identification, and tissue distribution of multiple new human exon 1. Journal of Molecular Endocrinology 35 283-292.

Wallace AD, Wheeler TT \& Young DA 1997 Inducibility of E4BP4 suggests a novel mechanism of negative gene regulation by glucocorticoids. Biochemical and Biophysical Research communications 232 403-406. 
Yoshida NL, Miyashita T, U M, Yamada M, Reed JC, Sugita Y \& Oshida T 2002 Analysis of gene expression patterns during glucocorticoidinduced apoptosis using oligonucleotide arrays. Biochemical and Biophysical Research Communications 293 1254-1261.

Yudt MR \& Cidlowski JA 2001 Molecular identification and characterization of $\mathrm{a}$ and $\mathrm{b}$ forms of the glucocorticoid receptor. Molecular Endocrinology 15 1093-1103.

Zhang W, Zhang J, Kornuc M, Kwan K, Frank R \& Nimer SD 1995 Molecular cloning and characterization of NF-IL3A, a transcriptional activator of the human interleukin-3 promoter. Molecular and Cellular Biology 15 6055-6063.
Zhang T, Haws P \& Wu Q 2004 Multiple variable first exons: a mechanism for cell- and tissue-specific gene regulation. Genome Research 14 79-89.

Zong J, Ashraf J \& Thompson EB 1990 The promoter and first, untranslated exon of the human glucocorticoid receptor gene are GC rich but lack consensus glucocorticoid receptor element sites. Molecular and Cellular Biology 10 5580-5585.

Received 27 September 2006 Accepted 3 October 2006 